\title{
Stress-Induced Activation of the Dynorphin/ $\kappa$-Opioid Receptor System in the Amygdala Potentiates Nicotine Conditioned Place Preference
}

\author{
Jeffrey S. Smith, Abigail G. Schindler, Emma Martinelli, Richard M. Gustin, Michael R. Bruchas, and Charles Chavkin \\ Department of Pharmacology, University of Washington, Seattle, Washington 98195-7280
}

\begin{abstract}
Many smokers describe the anxiolytic and stress-reducing effects of nicotine, the primary addictive component of tobacco, as a principal motivation for continued drug use. Recent evidence suggests that activation of the stress circuits, including the dynorphin/ $\kappa$-opioid receptor system, modulates the rewarding effects of addictive drugs. In the present study, we find that nicotine produced dose-dependent conditioned place preference (CPP) in mice. $\kappa$-Receptor activation, either by repeated forced swim stress or U50,488 (5 or $10 \mathrm{mg} / \mathrm{kg}$, i.p.) administration, significantly potentiated the magnitude of nicotine CPP. The increase in nicotine CPP was blocked by the $\kappa$-receptor antagonist norbinaltorphimine (norBNI) either systemically $(10 \mathrm{mg} / \mathrm{kg}$, i.p.) or by local injection in the amygdala $(2.5 \mu \mathrm{g})$ without affecting nicotine reward in the absence of stress. U50,488 (5 mg/kg, i.p.) produced anxiety-like behaviors in the elevated-plus maze and novel object exploration assays, and the anxiety-like behaviors were attenuated both by systemic nicotine $(0.5 \mathrm{mg} / \mathrm{kg}$, s.c. $)$ and local injection of norBNI into the amygdala. Local norBNI injection in the ventral posterior thalamic nucleus (an adjacent brain region) did not block the potentiation of nicotine CPP or the anxiogenic-like effects of $\kappa$-receptor activation. These results suggest that the rewarding effects of nicotine may include a reduction in the stress-induced anxiety responses caused by activation of the dynorphin/ $\kappa$-opioid system. Together, these data implicate the amygdala as a key region modulating the appetitive properties of nicotine, and suggest that $\kappa$-opioid antagonists may be useful therapeutic tools to reduce stress-induced nicotine craving.
\end{abstract}

\section{Introduction}

Despite widespread knowledge of the health risks associated with tobacco consumption (Changeux, 2010), $<10 \%$ of smokers who attempt to quit each year are successful, and tobacco relapse rates remain high despite current nicotine dependence treatments (Benowitz, 2008). The presence of stress has long been thought to increase the rewarding properties of tobacco and to increase the risk of relapse (McKennell, 1970; Daughton et al., 1990), but the mechanisms are not clear. Understanding the interactions between stress systems and nicotine reward may provide insights that could facilitate smoking cessation. The endogenous stress response includes activation of the dynorphin/ $\kappa$-opioid system (Chavkin et al., 1982; Smith and Lee, 1988; Bruchas et al., 2010), and growing evidence suggests that the $\kappa$-opioid system may play a significant role in modifying the rewarding properties of nicotine (Hasebe et al., 2004; Balerio et al., 2005; Marco et al., 2005; Ismayilova and Shoaib, 2010). In addition, $\kappa$-receptor antagonists have been demonstrated previously to alleviate somatic nic-

\footnotetext{
Received June 13, 2011; revised Nov. 29, 2011; accepted Dec. 6, 2011.

Author contributions: J.S.S., A.G.S., R.M.G., M.R.B., and C.C. designed research; J.S.S. and E.M. performed research; A.G.S., R.M.G., and M.R.B. contributed unpublished reagents/analytic tools; J.S.S. and C.C. analyzed data; J.S.S. and C.C. wrote the paper.

This work was supported by National Institute on Drug Abuse Grants DA07278, DA020570 and DA030074. The authors declare no competing financial interests.

Correspondence should be addressed to Dr. Charles Chavkin, Department of Pharmacology, Box 357280, University of Washington School of Medicine, Seattle, WA 98195-7280. E-mail: cchavkin@u.washington.edu.

DOI:10.1523/JNEUROSCI.2980-11.2012

Copyright $\odot 2012$ the authors $\quad 0270-6474 / 12 / 321488-08 \$ 15.00 / 0$
}

otine withdrawal signs (Jackson et al., 2010). Thus, the stress response encoded by the dynorphin/ $\kappa$-opioid system may act as one possible modulator of the appetitive properties of nicotine.

However, a broader range of interactions between the endogenous opioid systems and nicotinic reward mechanisms have been documented previously. Nicotine stimulates $\beta$-endorphin release in brain (Marty et al., 1985), and endogenous opioids released by nicotine occupy $\mu$-opioid receptors (Davenport et al., 1990). Similarly, nicotine administration increases metenkephalin expression (Dhatt et al., 1995; Isola et al., 2000) and prodynorphin expression (Isola et al., 2009). The roles of the endogenous opioids in mediating the rewarding and compensatory withdrawal effects of nicotine have not been fully resolved; however, mice having disruptions of their $\mu$-opioid receptor, $\beta$-endorphin, or proenkephalin genes show blunted nicotineconditioned reward (Berrendero et al., 2010), and the aversive responses to nicotine withdrawal are blunted in mice genetically lacking prodynorphin (Galeote et al., 2009). These results support the concept that the motivational effects of nicotine, including its anxiolytic and mildly euphorigenic effects, involve activation of the endorphin/enkephalin $\mu$ - and $\delta$-opioid systems, whereas the dysphoric, anxiogenic, and aversive effects experienced during nicotine withdrawal may involve activation of the dynorphin/ $\kappa$-opioid system (Jackson et al., 2010).

In humans and rodents, stress activation of the $\kappa$-opioid system elicits dysphoria-like responses, increases anxiety-like behaviors, and increases drug craving and the risk of relapse in animal models of drug addiction (Pfeiffer et al., 1986; Bals-Kubik 
et al., 1993; McLaughlin et al., 2003, 2006; Carlezon et al., 2006; Land et al., 2008; Schindler et al., 2010; Wittmann et al., 2009). Because stress exposure increases drug-seeking behaviors in humans and rodents (McKennell, 1970; Daughton et al., 1990; Shaham and Stewart, 1995; Shaham et al., 2000), this study tests the hypothesis that activation of the dynorphin/ $\kappa$-opioid receptor system by forced swim stress may enhance nicotine-seeking behaviors. Because stress is a complex stimulus that likely affects nicotine-dependent individuals differently than nondependent individuals, we chose to first describe the effects of forced swim on the initial response to nicotine in nondependent mice. For the first time we demonstrate that, during stress exposure, $\kappa$-receptor activation is necessary and $\kappa$-receptor activation in the amygdala alone is sufficient to increase nicotine-seeking behavior measured by conditioned place preference (CPP).

\section{Materials and Methods}

Animals. Wild-type male C57BL/6 mice (5-8 weeks old; $18-22$ g; Charles River) were used. Food and water were available ad libitum. Mice were handled daily for at least $3 \mathrm{~d}$ before testing. Protocols were approved by the University of Washington Institutional Animal Care and Use Committee.

Drugs. (-)-Nicotine bitartrate was purchased from Sigma-Aldrich. Norbinaltorphimine (norBNI)-HCl and $( \pm)$ U50,488 (2-(3,4dichlorophenyl)-N-methyl-N-[(1R,2R)-2-pyrrolidin-1-ylcyclohexyl] acetamide) were provided by the National Institute on Drug Abuse Drug Supply program and Tocris Bioscience. Nicotine and their saline controls were administered subcutaneously as described previously (Kota et al., 2007), and norBNI, U50,488, and their saline controls were administered intraperitoneally. Saline was given at $10 \mathrm{ml} / \mathrm{kg}$, norBNI at $10 \mathrm{mg} / \mathrm{kg}$, and $\mathrm{U} 50,488$ at $5 \mathrm{mg} / \mathrm{kg}$ unless noted otherwise.

Nicotine CPP. A balanced and unbiased three-compartment placeconditioning apparatus described previously (McLaughlin et al., 2006; Schindler et al., 2010) was used to measure nicotine CPP. Movement was recorded using video capture (Canon ZR90) and analyzed using Noldus Ethovision software (version 3.0). Briefly, mice were exposed to the entire apparatus for $20 \mathrm{~min}$, with the final $15 \mathrm{~min}$ recorded by video capture. On Days 2-4, mice were administered saline and confined to the saline-paired compartment for $20 \mathrm{~min}$. At least $4 \mathrm{~h}$ later, mice were administered nicotine and confined to the nicotine-paired compartment. Nicotine was given in the afternoon sessions to avoid confounding effects of acute nicotine withdrawal on the saline conditioning session. On Day 5, mice were allowed access to the entire apparatus for $20 \mathrm{~min}$, and time spent in each compartment was recorded during the final 15 min to assess preference (time spent on saline-paired side after training was subtracted from time spent on nicotine-paired side after training). One hour before the post-test, mice were administered either saline or U50,488 or received forced swim stress. Mice received the long-lasting $\kappa$-receptor-selective antagonist norBNI either $\sim 18 \mathrm{~h}$ before final preference testing, in accordance with previous behavioral CPP studies (Jackson et al., 2010; Schindler et al., 2010), or before nicotine training for dose-response analysis. The duration of norBNI antagonism in mice was previously shown to be $>2$ weeks (Horan et al., 1992; Bruchas et al., 2007).

Forced swim stress. Mice were exposed to two forced swim stress sessions as described previously (McLaughlin et al. 2003). Eighteen hours before the CPP post-test, mice were exposed to one $15 \mathrm{~min}$ swim in $30 \pm$ $1{ }^{\circ} \mathrm{C}$ water, without opportunity to escape. One hour before the post-test, mice were exposed to a second $15 \mathrm{~min}$ swim. Mice were then dried and returned to their home cage. Control mice received a saline injection and remained in their home cage.

Stereotaxic microinjections. Isoflurane-anesthetized mice were mounted on a stereotaxic alignment system (David Kopf Instruments). Mice were injected bilaterally in the amygdala $( \pm 3.1 \mathrm{~mm}$ lateral, -1.8 $\mathrm{mm}$ posterior, $5 \mathrm{~mm}$ depth from bregma) or in the ventral posterior thalamic nucleus (VPN; $\pm 1.37 \mathrm{~mm}$ lateral, $-1.82 \mathrm{~mm}$ posterior, 4.35 $\mathrm{mm}$ depth) with $1 \mu \mathrm{l}$ of a $2.5 \mathrm{~g} / \mathrm{L}$ solution of norBNI dissolved in saline vehicle, or injected with saline as described previously (Bruchas et al.,
2009). A subset of injections contained fluospheres (Invitrogen) to confirm location of the syringe tip. All of these animals had fluospheres present within the target region. In addition, further anatomical confirmations of selective $\kappa$-receptor inactivation were conducted with immunohistochemistry as described below. Animals were allowed to recover for 4-6 d after injection before behavioral testing.

Immunohistochemistry. Mice were locally injected with either saline or norBNI as described above. Mice were anesthetized with pentobarbital, then perfused intracardially with $4 \%$ paraformalde in phosphate buffer (PB; $0.1 \mathrm{M}$ sodium phosphate, $\mathrm{pH}$ 7.4). Thirty minutes before cardioperfusion, mice were systemically injected with $15 \mathrm{mg} / \mathrm{kg}$ U50,488, which results in $\kappa$-receptor activation and subsequent receptor phosphorylation. Brains were dissected and cryoprotected with a solution of $30 \%$ $(\mathrm{w} / \mathrm{v})$ sucrose in $\mathrm{PB}$ at $4^{\circ} \mathrm{C}$ overnight, cut into $40 \mu \mathrm{m}$ sections, and placed in $\mathrm{PB}$ until processing. Affinity-purified rabbit anti-phospho- $\kappa$-receptor (KORp) antibody (1:150 dilution; Abcam) diluted in blocking buffer (PBS containing $0.3 \%$ Triton X-100 and 5\% normal goat or donkey sera) was used to access KORp immunoreactivity (ir) as in protocols described previously (Bruchas et al., 2007, 2009; Land et al., 2008).

Anxiety and pain testing. Anxiety testing was conducted under dim light as described previously (Bruchas et al., 2009). One hour before testing, mice received either U50,488 or saline. Approximately $30 \mathrm{~min}$ before testing, mice received nicotine $(0.5 \mathrm{mg} / \mathrm{kg})$ or saline.

For the elevated-plus maze (EPM), mice were placed in the center sector facing toward an open arm and then allowed to roam freely for 6 min. Movement through arms was recorded using video capture (Canon ZR90) and analyzed using Noldus Ethovision software (version 3.0).

To test the latency to explore a novel object, a bottle cap was placed at the far side of a rectangular chamber $(46 \times 23 \times 20 \mathrm{~cm})$ with a laminated white floor. Mice were placed in the chamber on the opposite side, facing the object. Video analysis of latency to approach was done by an investigator blind to treatment.

For the tail withdrawal assay, tail withdrawal latency was assessed in $52.5 \pm 0.5^{\circ} \mathrm{C}$ water, as described previously (Melief et al., 2010).

Data analysis. Data are expressed as means \pm SE. Differences between groups were determined using independent $t$ tests or one-way ANOVA followed by Dunnet's (for comparisons between relevant groups and the control group). For experiments having a two-by-two factorial design, two-way ANOVAs followed by Bonferroni post hoc analysis were conducted to test for significance. Statistical analyses were conducted using GraphPad Prism (version 4.0) (GraphPad Software). Individual values greater than two SDs away from the mean were excluded.

\section{Results}

KOR activation is necessary for stress-induced potentiation of nicotine place preference

In the nicotine CPP paradigm used (Fig. 1), male C57BL/6 mice showed significant nicotine CPP to $0.5 \mathrm{mg} / \mathrm{kg}$ of nicotine $(n=$ $12-27$; one-way ANOVA, $F_{(4,79)}=3.84, p<0.01$; Dunnett's post hoc test, 0 vs $0.5 \mathrm{mg} / \mathrm{kg}, p<0.05$ ), with a slightly higher dose producing no preference (Dunnett's post hoc test, 0 vs $0.7 \mathrm{mg} / \mathrm{kg}$, $p>0.05$ ) (Fig. 2A). A narrow and biphasic response to nicotine has been noted previously (Picciotto, 2003; Kota et al., 2007; Zhu et al., 2007) and is consistent with human reports of narrow dose-dependent changes in mood (Gilbert et al., 1992; Kalman, 2002). Interestingly, we found that norBNI pretreatment produced a significant switch in the time spent in the $1.0 \mathrm{mg} / \mathrm{kg}$ nicotine-paired chamber, but did not interfere with $0.5 \mathrm{mg} / \mathrm{kg}$ nicotine place preference, suggesting that the aversive effects of $1.0 \mathrm{mg} / \mathrm{kg}$ nicotine were mediated by dynorphin release $(n=$ 11-27; two-way ANOVA; interaction, $F_{(1,59)}=8.11, p<0.01$; Bonferroni's post hoc test, control plus $0.5 \mathrm{mg} / \mathrm{kg}$ nicotine vs norBNI plus $0.5 \mathrm{mg} / \mathrm{kg}$ nicotine, $p>0.05$; control plus $1.0 \mathrm{mg} / \mathrm{kg}$ nicotine vs norBNI plus $1.0 \mathrm{mg} / \mathrm{kg}$ nicotine, $p<0.01)$. These results are consistent with the observation that the acquisition of $0.5 \mathrm{mg} / \mathrm{kg}$ nicotine place preference by prodynorphin knock-out mice was not different from wild-type littermates (Galeote et al., 2009). 
Nicotine training

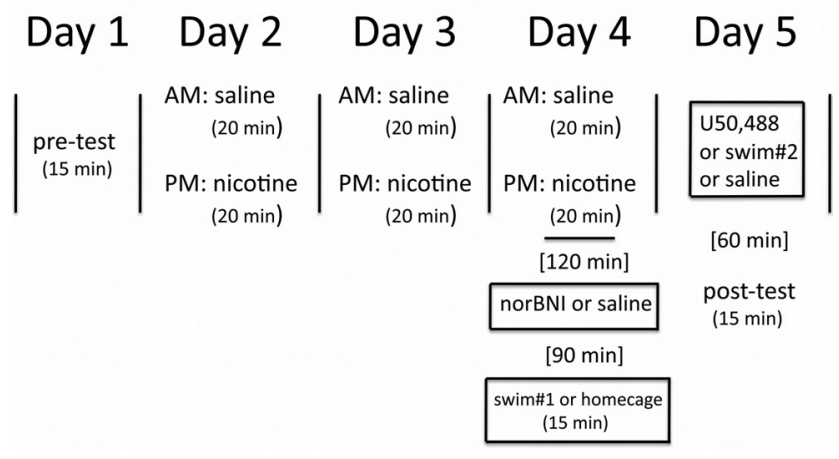

Figure 1. Time line of the nicotine conditioned place preference paradigm used in this study.

Forced swim stress exposure more than doubled the place preference resulting from $0.5 \mathrm{mg} / \mathrm{kg}$ nicotine (Fig. 2 B). Furthermore, pretreatment with norBNI before the first forced swim episode blocked the subsequent stress-induced potentiation of nicotine CPP (Fig. $2 B)(n=16-27$; two-way ANOVA; interaction, $F_{(1,76)}=9.07, p<0.01$; Bonferroni's post hoc test, saline plus swim vs norBNI plus swim, $p<0.001$; saline plus home cage vs saline plus swim, $p<0.01)$. In this experiment, release of the endogenous dynorphins by forced swim was confirmed by showing that tail withdrawal latencies from warm water increased from $1.8 \mathrm{~s}$ (before swim) to $2.9 \mathrm{~s}$ immediately following the second swim. Whereas mice pretreated with norBNI did not show a significant change in tail withdrawal latency following forced swim (1.9 s before swim to $2.1 \mathrm{~s}$ after swim; $n=8-16$; repeatedmeasures two-way ANOVA; interaction, $F_{(1,22)}=5.90, p<0.05$; Bonferroni's post hoc test, saline pre-test vs saline post-test, $p<$ 0.001 ; norBNI pre-test vs norBNI post-test, $p>0.05$ ). In addition, norBNI pretreatment in the absence of stress had no effect on nicotine place preference (Fig. $2 \mathrm{~B}$ ). This lack of effect by norBNI alone suggests that $\kappa$-receptor antagonism did not interfere with associative learning or spatial memory responsible for nicotine place preference.

\section{$\kappa$-Receptor activation is also sufficient to potentiate nicotine place preference}

Because forced swim stress exposure likely activates multiple stress systems in brain, we next asked whether $\kappa$-receptor activation by U50,488 was also sufficient to potentiate nicotine place preference. Paralleling the timing in the swim paradigm, mice were injected with U50,488 $1 \mathrm{~h}$ before the nicotine CPP posttest. In a dose-dependent manner, U50,488 increased nicotine place preference in mice trained with $0.5 \mathrm{mg} / \mathrm{kg}$ nicotine (Fig. $3 A)\left(n=10-27\right.$; one-way ANOVA, $F_{(3,74)}=5.96, p<0.0012$; Dunnett's post hoc test, 0 vs $2.5 \mathrm{mg} / \mathrm{kg}, p>0.05 ; 0 \mathrm{vs} 5 \mathrm{mg} / \mathrm{kg}$, $p<0.05 ; 0$ vs $10 \mathrm{mg} / \mathrm{kg}, p<0.01)$. The increased nicotine place preference caused by $5 \mathrm{mg} / \mathrm{kg}$ U50,488 was blocked by norBNI (Fig. $3 B)(n=20-27$; two-way ANOVA; interaction, $F_{(1,86)}=5.35, p<0.05$; Bonferroni's post hoc test, saline plus U50,488 vs norBNI plus U50,488, $p<0.01$; saline plus saline vs saline plus U50,488, $p<0.05)$. Although a high dose of U50,488 $(10 \mathrm{mg} / \mathrm{kg})$ significantly reduced ambulatory behavior, the $5 \mathrm{mg} / \mathrm{kg}$ dose that significantly potentiated nicotine place preference had no significant effect on locomotion (mean \pm SE, saline, $3853 \pm 854 \mathrm{~cm} ; 5 \mathrm{mg} / \mathrm{kg}$ U50,488, $3196 \pm 110 \mathrm{~cm} ; 10$ $\mathrm{mg} / \mathrm{kg} \mathrm{U} 50,488,2167 \pm 789 \mathrm{~cm} ; n=10-17$; one-way ANOVA, $F_{(2}$, ${ }_{35)}=5.91, p<0.01$; Dunnett's post hoc test, 0 vs $5 \mathrm{mg} / \mathrm{kg}, p>0.05$;
0 vs $10 \mathrm{mg} / \mathrm{kg}, p<0.01)$. These data support the conclusion that $\kappa$-receptor activation is both necessary and sufficient for the stress-induced increase in nicotine place preference.

\section{Anxiety-like behavior caused by $\kappa$-receptor activation is ameliorated by nicotine}

To assess the anxiety state of the mice, we used both the latency to explore novel object assay and EPM. Matching the timing of drug injection in the CPP experiment, we injected $5 \mathrm{mg} / \mathrm{kg}$ U50,488 or saline $1 \mathrm{~h}$ before anxiety testing, followed by a nicotine $(0.5 \mathrm{mg} /$ $\mathrm{kg}$ ) or saline injection $30 \mathrm{~min}$ before anxiety testing (Fig. 4A). The latency to explore a novel object was significantly increased by U50,488 compared with saline-treated mice (Fig. 4B). Although nicotine alone had no effect, the increase in latency to explore caused by $\kappa$-receptor activation was blocked by nicotine (Fig. $2 B)\left(n=12-15\right.$; two-way ANOVA; interaction, $F_{(1,51)}=$ 4.09, $p<0.05$; Bonferonni's post hoc test, saline plus nicotine vs $\mathrm{U} 50,488$ plus nicotine, $p<0.05$; saline plus saline vs $\mathrm{U} 50,488$ plus saline, $p<0.01)$.

Nicotine also ameliorated $\kappa$-receptor activation-induced anxiety-like behavior in the EPM. Mice receiving U50,488 spent significantly less time in open arms than controls. This decreased time spent in open arms was reversed by nicotine (Fig. 4C) $\left(n=7-9\right.$; two-way ANOVA; interaction, $F_{(1,27)}=6.09, p<$ 0.05; Bonferonni's post hoc test, saline plus nicotine vs U50,488 plus nicotine, $p<0.05$; saline plus saline vs U50,488 plus saline, $p<0.05)$. No significant differences in locomotor activity were observed between treatment groups during the 6 min EPM testing (Fig. 4D) ( $n=7-9$; two-way ANOVA; interaction, $F_{(1,27)}=$ $0.80, p>0.05$; all Bonferonni post hoc comparisons, $p>0.05)$. The novel object and EPM results suggest that the anxiety-like responses to $\kappa$-receptor activation could be reduced by nicotine administration and support the hypothesis that nicotine reward was increased by its anxiolytic actions.

\section{$\kappa$-Receptor activation in the amygdala is necessary for both U50,488-induced anxiety-like behavior and potentiation of nicotine place preference}

To probe the influence of nicotine on $\kappa$-receptor-dependent neural circuits influencing nicotine place preference and anxiety-like behaviors, we injected norBNI or saline locally into specific brain regions as described previously (Bruchas et al., 2007, 2009; Land et al., 2008). Bilateral injection of $2.5 \mu \mathrm{g}$ norBNI into the amygdala, but not $1 \mu \mathrm{l}$ saline, blocked the increase in nicotine place preference induced by $5 \mathrm{mg} / \mathrm{kg} \mathrm{U} 50,488$ (Fig. $5 C$ ) ( $n=10-11$; two-way ANOVA; interaction, $F_{(1,38)}=2.35, p=0.13$; Bonferonni's post hoc test, saline plus U50,488 vs norBNI plus U50,488, $p<0.05$; saline plus saline vs saline plus U50,488, $p<0.05$ ). Local injection of norBNI, but not saline, bilaterally into the amygdala also blocked 5 $\mathrm{mg} / \mathrm{kg}$ U50,488-induced anxiety-like behavior in the EPM (Fig. 5D) $\left(n=7\right.$ per treatment; two-way ANOVA; interaction, $F_{(1,24)}=5.23$, $p<0.05$; Bonferonni's post hoc test, saline plus U50,488 vs norBNI plus U50,488, $p<0.01$ ). In addition, bilateral injection of norBNI had no effect on total locomotor activity or on fraction of time in the open arm in the absence of U50,488 (Fig. 5D). The lack of norBNI effect on EPM behavior under the nonstressful, dim-light conditions used is consistent with prior results (Bruchas et al., 2009).

At the conclusion of the behavioral assessments, we confirmed that stereotaxic norBNI injection locally blocked $\kappa$-receptors in the amygdala by injecting $15 \mathrm{mg} / \mathrm{kg}$ U50,488 30 min before paraformaldehyde perfusion and subsequently immunostaining with a phosphoselective antibody (KORp-ir) that detects $\kappa$-receptors phosphorylated by G-protein receptor kinase 
A

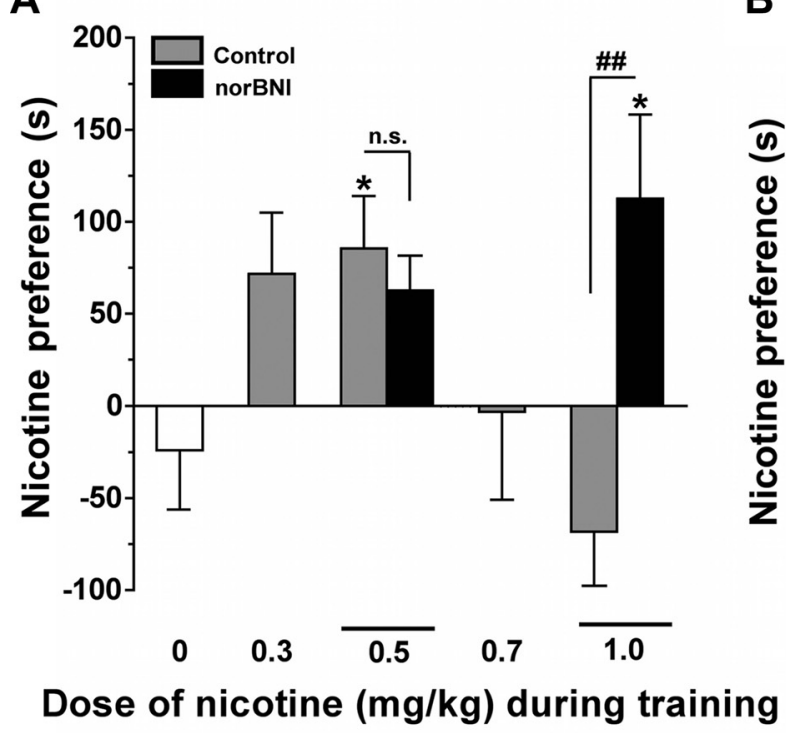

B

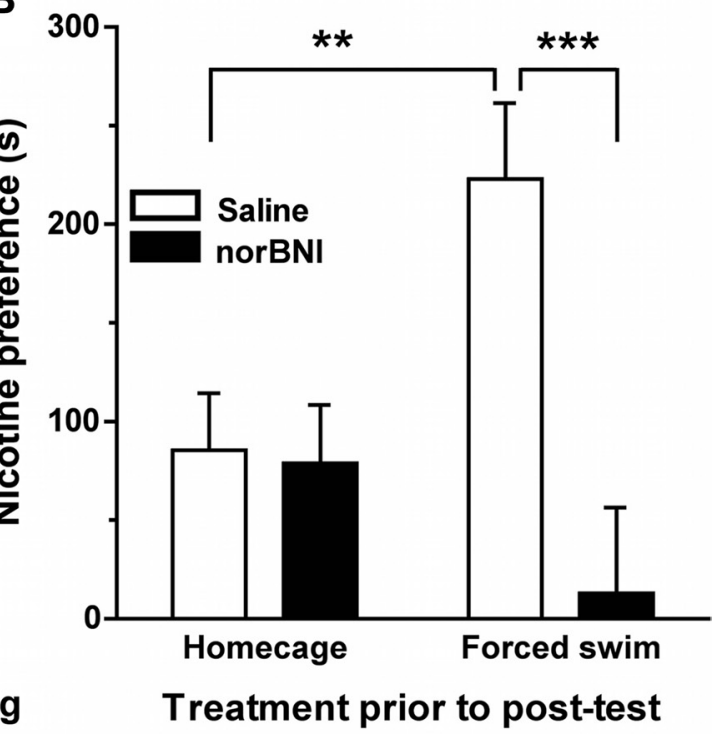

Figure 2. $\quad \kappa$-Receptor activation by forced swim stress exposure potentiates nicotine place preference. $\boldsymbol{A}$, Dose-dependent nicotine place preference on assessed on Day 5 . Pretreatment with 10 $\mathrm{mg} / \mathrm{kg}$ norBNI before nicotine training did not significantly affect place preference produced by $0.5 \mathrm{mg} / \mathrm{kg}$ nicotine; however, norBNI pretreatment switched the place aversion produced by 1.0 $\mathrm{mg} / \mathrm{kg}$ nicotine to a place preference. $\boldsymbol{B}$, Nicotine $(0.5 \mathrm{mg} / \mathrm{kg})$ place preference was significantly increased by two exposures to forced swim stress before the post-test. Administration of $10 \mathrm{mg} / \mathrm{kg}$ norBNI before swim blocked this increase, whereas norBNI given to a time-matched control group in the absence of swim did not affect nicotine place preference ( $n=11-27$ animals per group). n.s., Not significant. ${ }^{*} p<0.05 ;{ }^{* *} p<0.01$; ${ }^{* *} p<0.001$; ${ }^{\# \#} p<0.01$.

3 following agonist activation (Bruchas et al., 2007, 2009; Land et al., 2008). Consistent with previous results (Bruchas et al., 2009), the reduction in KORp-ir caused by local norBNI injection was restricted to the amygdala (Fig. 5A).

In contrast, local injection of norBNI in the VPN, a region dorsal and medial to the amygdala, did not block either potentiation of nicotine place preference (Fig. $5 E)(n=8-11$; two-way ANOVA; interaction, $F_{(1,33)}=0.12, p>0.05$; main effect of U50,488 vs saline, $p<0.05$ ) or anxiety-like behavior in the EPM (Fig. $5 F)\left(n=6-7\right.$; two-way ANOVA; interaction, $F_{(1,23)}=0.22$, $p>0.05$; main effect of U50,488 vs saline, $p<0.05)$ resulting from systemic U50,488 (5 mg/kg) administration. Because the potentiation of nicotine place preference was blocked by local inactivation of $\kappa$-receptors in a brain region shown previously to be required for dynorphin-dependent anxiety-like behaviors (Bruchas et al., 2009; Knoll et al., 2011), these results support the hypothesis that the anxiolytic effects of nicotine underlie the nicotine place preference potentiation caused by stress-induced activation of dynorphin/ $\kappa$-opioid system.

\section{Discussion}

$\boldsymbol{\kappa}$-Receptor regulation of conditioned place preference While the involvement of endorphin/ $\mu$-opioid system is well known to mediate both the acute effects of stress as well as effects of nicotine (Corrigall et al., 1988; Berrendero et al., 2002; Ribeiro et al., 2005; Liu and Jernigan 2011), less is known about the involvement of the dynorphin/ $\kappa$-opioid system in the rewarding properties of nicotine. The principal finding of this study was that $\kappa$-receptor activation either by forced swim stress or agonist treatment significantly potentiated nicotine place preference. In addition, $\kappa$-receptor activation caused anxiety-like behaviors that were also blocked by nicotine. Both the potentiation of nicotine CPP and anxiety-like behaviors could be blocked by local inactivation of $\kappa$-receptors in the amygdala. In addition, the aversive effects of high doses of nicotine were mediated by $\kappa$-receptor activation. $\kappa$-Receptor activation was both necessary and sufficient to potentiate nicotine-seeking behavior, similar to the effect of $\kappa$-receptor activation demonstrated previously on cocaine and ethanol preference (McLaughlin et al., 2006; Schindler et al., 2010; Nealey et al., 2011; Walker et al., 2011). The efficacy of norBNI in blocking the stress-induced potentiation of nicotine CPP supports the concept that $\kappa$-receptor antagonists may be effective smoking cessation treatments (Jackson et al., 2010).

In this experimental design, $\kappa$-receptor activation was initiated before assessing the conditioned preference. Previous studies have demonstrated that coadministration of $\kappa$-receptor agonists with rewarding drugs will block cocaine CPP (Shippenberg et al., 1996, 2007), but if $\kappa$-receptor activation by stressinduced dynorphin release or agonist administration precedes
A

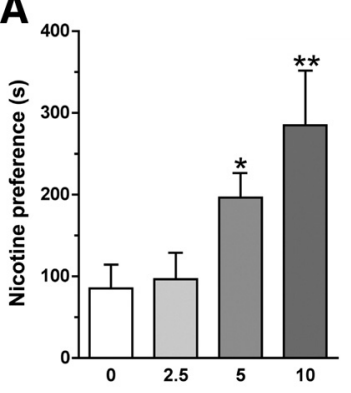

Dose of U50,488 (mg/kg) prior to post-test
B

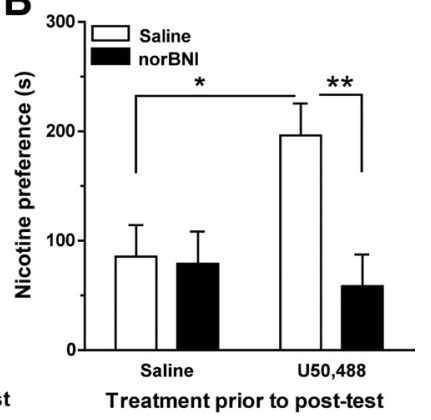

Figure 3. $A$, Similar to the effects of forced swim stress-induced dynorphin release, pharmacological $\kappa$-receptor activation by U50,488 $1 \mathrm{~h}$ before the post-test on Day 5 resulted in a

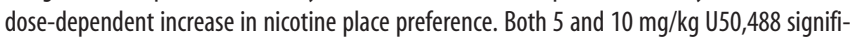
cantly increased nicotine place preference compared with saline-treated controls. $\boldsymbol{B}$, The effects of $5 \mathrm{mg} / \mathrm{kg} \mathrm{U50,488}$ on nicotine place preference were blocked by $10 \mathrm{mg} / \mathrm{kg}$ norBNI administered $\sim 18 \mathrm{~h}$ before the post-test, whereas norBNI pretreatment in the absence of U50,488 did not significantly affect nicotine place preference $\left(n=10-27\right.$ animals per group). ${ }^{*} p<0.05$; ${ }^{* *} p<0.01$. 
the cocaine conditioning session, the rewarding valence of cocaine will be potentiated (McLaughlin et al., 2006; Schindler et al., 2010). We presume that the euphorigenic effects of cocaine are increased when the mouse enters the associative conditioning session in a dysphoric state, but this relationship is difficult to assess directly. In the present study, a similar interaction between prior $\kappa$-receptor activation and the enhanced rewarding valence of nicotine was evident, suggesting that potentiation of nicotine-seeking behavior was the consequence of the anxiolytic effects of nicotine. Further studies will be needed to dissect the neural circuitry regulating anxiety-like and dysphoric-like behaviors, and to determine whether potentiation of drug-seeking behavior regulated by the $\kappa$-receptor system is mediated by similar intracellular mechanisms.

In seemingly contradictory results, $\kappa$-opioid agonists have been demonstrated to reduce cocaine-seeking behavior in rodents when $\kappa$-receptor agonists are administered concurrently or immediately before cocaine self-administration testing or final preference testing of cocaine CPP (Shippenberg et al., 1996, 2007). Studies have demonstrated that acute $\kappa$-receptor activation by $\kappa$-receptor agonists interferes with memory (Castellano et al., 1988; Schindler et al. 2010). In addition, U50,488 has been shown to suppress learning and memory mechanisms in a time-dependent manner. Treatment with U50,488 15 min prior, but not $60 \mathrm{~min}$ prior, to an object recognition task has been demonstrated to interfere with memory retrieval (Schindler et al., 2010). Acute disruption of memory retrieval by $\kappa$-receptor agonists in associative learning assays used to assess drug-seeking behavior may explain discrepancies between studies. In the present study, we activated $\kappa$-receptors before the post-test to avoid potential effects of stress on associative learning mechanisms and focus on the response of the animals to the previously learned cues. Results from the present study suggest that $\kappa$-receptor activation enhances the rewarding valence of nicotineassociated cues rather than affecting associative learning or recall mechanisms.

Interactions of the stress-response system encoded through the $\kappa$-receptor system on both drug-seeking and anxiety-like behaviors

Stress has long been thought to elevate the immediate rewarding properties of tobacco and to increase the risk of relapse (McKennell, 1970; Daughton et al., 1990). Stress is well known to reinstate drug-seeking behaviors in many abused substances, including nicotine (Marlatt and Gordon, 1985; Shaham and Stewart, 1995; Lê et al. 1998; Buczek et al., 1999; Shaham et al., 2000). We showed previously that stress given either before cocaine conditioning sessions or just before the post-test results in potentiation of cocaine-seeking behavior (McLaughlin et al., 2003, 2006; Schindler et al., 2010).

Notably, our observed forced swim stress exposure led to a more than doubling of the nicotine place preference, providing

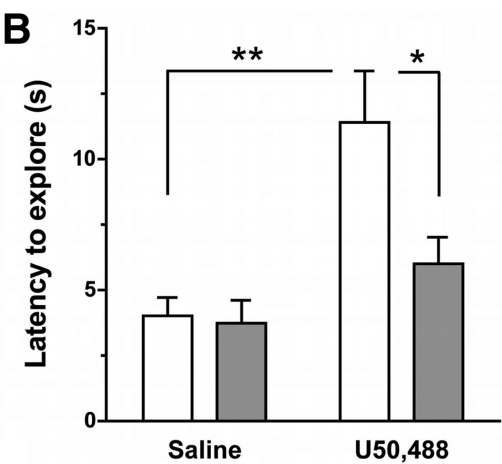

D Treatment prior to exploration testing

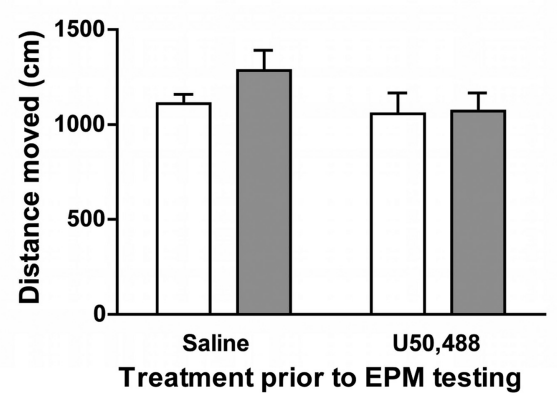

Treatment prior to EPM testing

Figure 4. Nicotine alleviates anxiety-like behavior resulting from selective $\kappa$-receptor activation. $A$, Time line of the anxietytesting paradigm. $\boldsymbol{B}, \mathrm{U} 50,488(5 \mathrm{mg} / \mathrm{kg}$ ) administered $1 \mathrm{~h}$ before testing increased anxiety-like behavior (increased latency to ( anxiety effect was reversed by nicotine $(0.5 \mathrm{mg} / \mathrm{kg})$. $\boldsymbol{D}$, No significant differences in locomotion were observed between treatment groups during the 6 min EPM session ( $n=7-15$ animals per group). ${ }^{*} p<0.05$; ${ }^{* *} p<0.01$.

our paradigm with predictive validity to human tobacco usage. Forced swim stress also increased tail withdrawal latency, commonly used for opioid analgesia testing and for $\kappa$-receptordependent stress-induced analgesia (McLaughlin et al., 2003; Melief et al., 2010). While $\kappa$-receptor antagonism by norBNI blocked stress-induced increases in nicotine place preference, it did not disrupt associative learning or spatial memory mechanisms necessary to perform the CPP behavioral task. These results agree with studies where lack of a functioning dynorphin/ $\kappa$-opioid receptor system did not effect memory retrieval, learning, or expression of place preference (Land et al., 2008; Jackson et al., 2010; Schindler et al., 2010; Nealey et al., 2011).

We additionally demonstrate that anxiety-like effects caused by $\kappa$-receptor-selective activation were ameliorated by subsequent low doses of nicotine. We used two assays, EPM and latency to explore a novel object, to model anxiety. The EPM has high predictive validity for identifying anxiolytic and anxiogenic pharmacological agents in humans, and a decrease in time spent in the open arms of the EPM by rodents strongly correlates with an anxious state in humans (Hogg, 1996; Ramos, 2008). We further supported our observation that nicotine reduces $\kappa$-receptor mediated anxiety-like behavior through the latency to explore a novel object assay. This test, like the plus maze, examines anxietylike behavior in rodents (Heisler et al., 1998). Activation of $\kappa$-receptors by U50,488 elicits anxiety-like behaviors, and both prodynorphin knock-out and $\kappa$-receptor antagonists reduce anxiety-like behaviors (Wittmann et al., 2009; Peters et al., 2011). Previous reports also show that low doses of systemic nicotine have anxiolytic effects (Costall et al., 1989; Brioni et al., 1994; File 
A

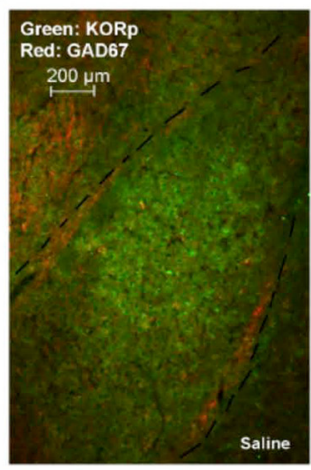

C

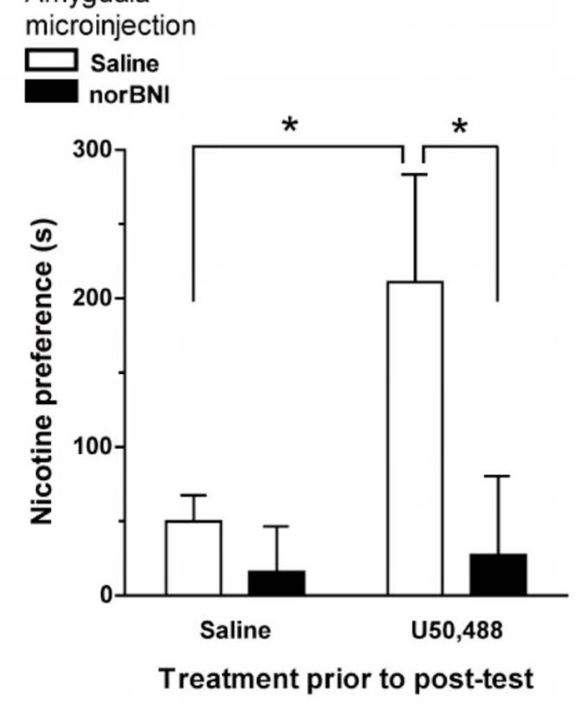

E
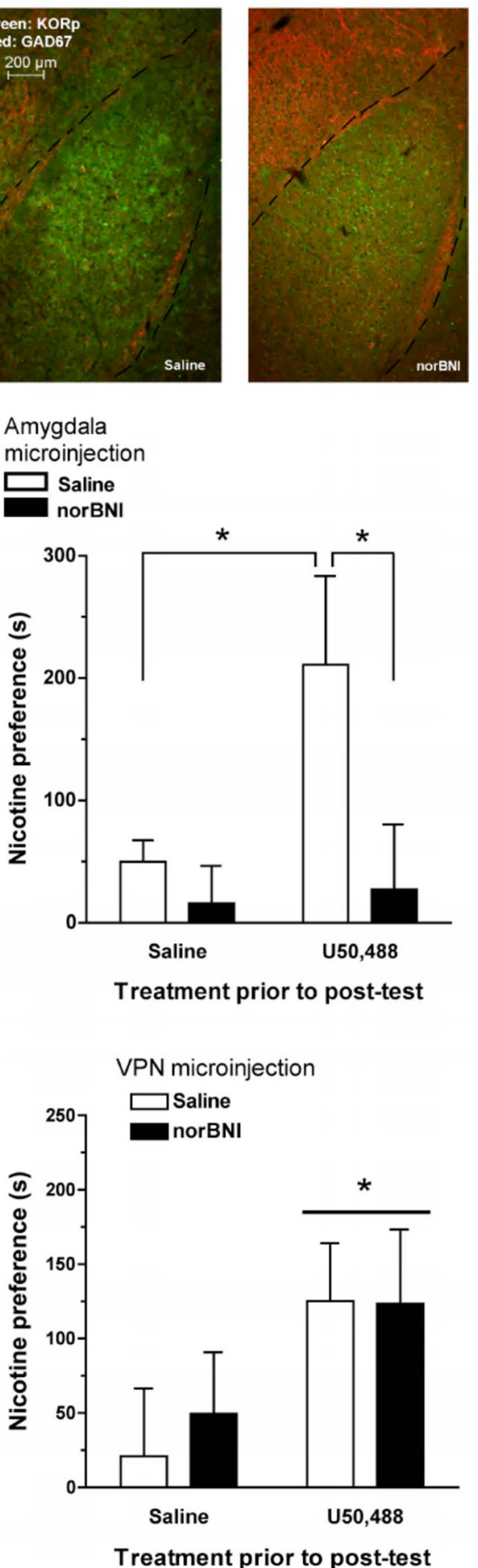

B

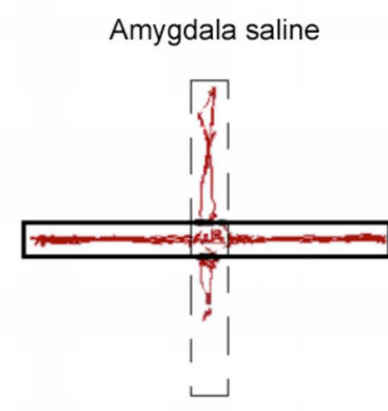

D Amygdala microinjection

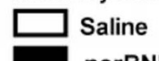
norBNI
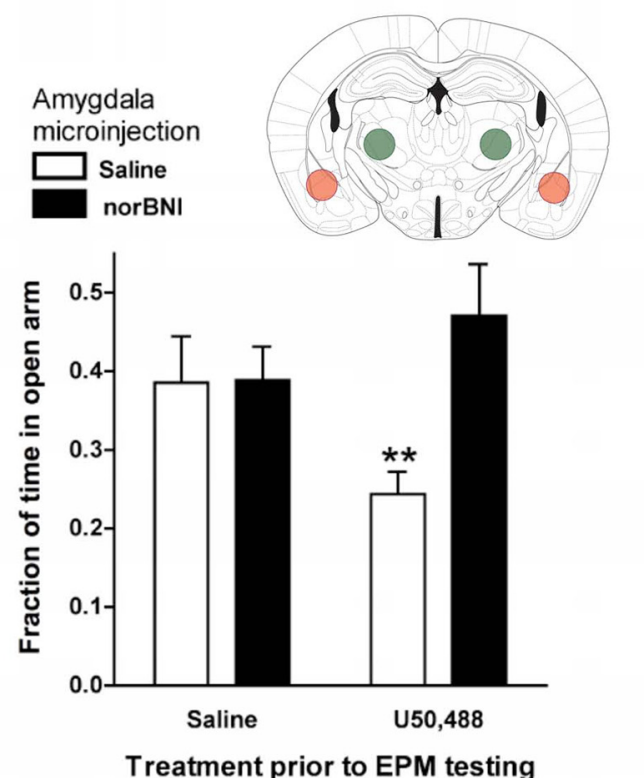

$\mathbf{F}$

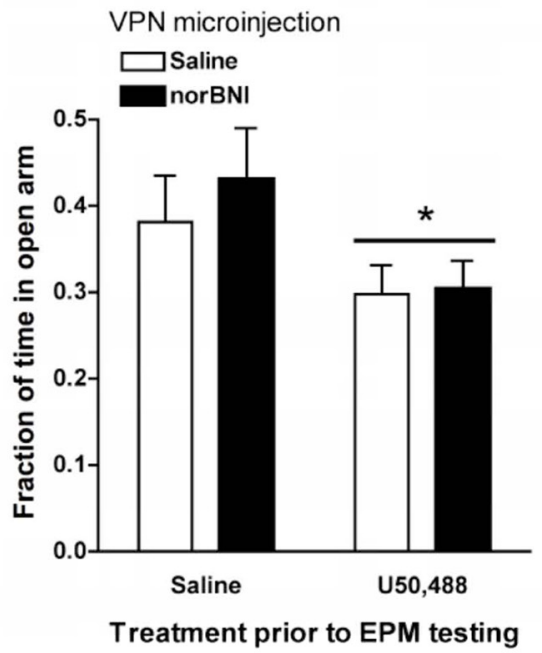

Figure 5. Bilateral local injection of norBNl into the amygdala, but not the VPN, prevents anxiety-like behavior and potentiation of nicotine-seeking behavior resulting from $\kappa$-receptor activation. $A$, Local injection of norBNI into the amygdala, but not saline, blocked the U50,488-induced increase in $\kappa$-receptor phosphorylation (KORp-ir) (green). GAD67-ir is also shown in red. B, Representative traces of EPM behavior in animals receiving local injections of either saline or norBNI (red, saline amygdala injection; blue, norBNI amygdala injection). C, Amygdala injection of norBNI, but not saline, blocked an increase in nicotine place preference caused by systemic U50,488. D, Amygdala injection of norBNI, butnotsaline, also blocked U50,488-induced anxiety-like behavior in the EPM. Inset, Schematic of a coronal brain slice 1.82 $\mathrm{mm}$ caudal to bregma indicating injection sites for the amygdala (red) and VPN (green). $\boldsymbol{E}, \boldsymbol{F}$, Bilateral local injection of norBNI into the VPN, an off-target control brain region dorsal and medial to the amygdala, did not block an increase in nicotine place preference $(\boldsymbol{E})$ or block anxiety-like behaviors in the EPM resulting from systemic U50,488 administration $(\boldsymbol{F})\left(n=6-11\right.$ animals per group). ${ }^{*} p<0.05 ;{ }^{* *} p<0.01$.

et al., 1998), although this is dependent on the time of administration and dose, as low doses of nicotine are reported to produce anxiolytic effects, whereas high doses generated anxiogenic responses (File et al., 1998; Balerio et al., 2005).
Amygdala regulation of anxiety-like and reward-seeking behaviors

The results support the conclusion that activation of $\kappa$-receptors in the amygdala produce anxiety-like behavioral responses (Land 
et al., 2008; Bruchas et al., 2009). The amygdala is a region known to encode anxiety and value, and to mediate aspects of drugseeking behavior (LeDoux, 2003; Tye et al., 2008; Koob, 2009; Jenison et al., 2011). Because the amygdala also coexpresses $\alpha 4 \beta 2$ and $\alpha 7 \mathrm{nACh}$ receptors (Changeux, 2010), it is plausible that the interaction between the nicotinic and $\kappa$-opioid systems occurs in this brain region, but this hypothesis will require further circuit analysis. Both the basolateral amygdala (BLA) and central nucleus of the amygdala (CeA) play key roles in mediating reward and anxiety-like behavior. The BLA regulates CeA activity (LeDoux, 2003), and a crucial output region of the CeA is the central medial nuclei, which when excited mediate autonomic and behavioral responses associated with anxiety (Tye et al., 2011). Previous studies implicated stress-response signaling in the CeA, as well as the bed nucleus of the stria terminalis, following foot shock stress exposure as critical for the reinstatement of cocaineseeking behavior (Erb and Stewart, 1999; Leri et al., 2002). Fibers projecting from the BLA to the nucleus accumbens influence dopamine release in the ventral striatum, and selective activation of these fibers facilitates motivated behavior and reward seeking, while inactivation suppresses response to natural appetitive stimuli (Jones et al., 2010; Stuber et al., 2011). Further studies dissecting the role and location of $\kappa$-receptors in amygdala subnuclei may provide a more detailed understanding of anxiety-like and drug-seeking behaviors.

The insights gleaned from the present study suggest that stress-induced signaling results in a negative affective and anxiety-like state that leads to nicotine-seeking behavior. While $\kappa$-receptor antagonism may initially increase the dose range in which nicotine elicits place preference, it also prevents stressinduced increases in nicotine reward. Together, our findings suggest that $\kappa$-receptor antagonism may be a novel therapeutic tool to decrease nicotine-seeking behavior.

\section{References}

Balerio GN, Aso E, Maldonado R (2005) Involvement of the opioid system in the effects induced by nicotine on anxiety-like behaviour in mice. Psychopharmacol 181:260-269.

Bals-Kubik R, Ableitner A, Herz A, Shippenberg TS (1993) Neuroanatomical sites mediating the motivational effects of opioids as mapped by the conditioned place preference paradigm in rats. J Pharmacol Exp Ther 264:489-495.

Benowitz NL (2008) Clinical pharmacology of nicotine: implications for understanding, preventing, and treating tobacco addiction. Clin Pharmacol Ther 83:531-541.

Berrendero F, Kieffer BL, Maldonado R (2002) Attenuation of nicotineinduced antinociception, rewarding effects, and dependence in $\mu$-opioid receptor knock-out mice. J Neurosci 22:10935-10940.

Berrendero F, Robledo P, Trigo JM, Martín-García E, Maldonado R (2010) Neurobiological mechanisms involved in nicotine dependence and reward: participation of the endogenous opioid system. Neurosci Biobehav Rev 35:220-231.

Brioni JD, O’Neill AB, Kim DJ, Buckley MJ, Decker MW, Arneric SP (1994) Anxiolytic-like effects of the novel cholinergic channel activator ABT418. J Pharmacol Exp Ther 271:353-361.

Bruchas MR, Yang T, Schreiber S, Defino M, Kwan SC, Li S, Chavkin C (2007) Long- acting kappa opioid antagonists disrupt receptor signaling and produce noncompetitive effects by activating c-Jun N-terminal kinase. J Biol Chem 282:29803-29811.

Bruchas MR, Land BB, Lemos JC, Chavkin C (2009) CRF1-R activation of the dynorphin/kappa opioid system in the mouse basolateral amygdala mediates anxiety-like behavior. PLoS 4:e8528.

Bruchas MR, Land BB, Chavkin C (2010) The dynorphin-kappa opioid system as a modulator of stress-induced and pro-addictive behaviors. Brain Research 1314:44-55.

Buczek Y, Lê AD, Wang A, Stewart J, Shaham Y (1999) Stress reinstates nicotine seeking but not sucrose solution seeking in rats. Psychopharmacol (Berl) 144:183-188.

Carlezon WA Jr, Beguin C, DiNieri JA, Baumann MH, Richards MR, Todtenkopf MS, Rothman RB, Ma Z, Lee DY, Cohen BM (2006) Depressive-like effects of the kappa-opioid receptor agonist salvinorin A on behavior and neurochemistry in rats. J Pharmacol Exp Ther 316:440-447.

Castellano C, Libri V, Ammassari-Teule M (1988) The amygdala mediates the impairing effect of the selective kappa-opioid receptor agonist U-50,488 on memory in CD1 mice. Behav Brain Res 30:259-263.

Changeux JP (2010) Nicotine addiction and nicotinic receptors: lessons from genetically modified mice. Nat Rev Neurosci 11:389-401.

Chavkin C, James IF, Goldstein A (1982) Dynorphin is a specific endogenous ligand of the $\kappa$-opioid receptor. Science 215:413-415.

Corrigall WA, Herling S, Coen KM (1988) Evidence for opioid mechanisms in the behavioral effects of nicotine. Psychopharmacol 96:29-35.

Costall B, Elizabeth MK, Naylor RJ, Onaivi E (1989) The actions of nicotine and cocaine in a mouse model of anxiety. Pharmacol Biochem Behav 33:97-203.

Daughton DM, Roberts D, Patil KD, Rennard SI (1990) Smoking cessation in the workplace: evaluation of relapse factors. Prev Med 19:227-230.

Davenport KE, Houdi AA, Van Loon GR (1990) Nicotine protects against mu opioid receptor antagonism by $\beta$-funaltrexamine: evidence for nicotine induced release of endogenous opioids in brain. Neurosci Lett 113:40-46.

Dhatt RK, Gudehithlu KP, Wemlinger TA, Tejwani GA, Neff NH, Hadjiconstantinou M (1995) Preproenkephalin mRNA and methionine encephalin content are increased in mouse striatum after treatment with nicotine. J Neurochem 64:1878-1883.

Erb S, Stewart J (1999) A role for the bed nucleus of the stria terminalis, but not the amygdala, in the effects of corticotropin-releasing factor on stressinduced reinstatement of cocaine seeking. J Neurosci 19:RC35.

File SE, Kenny PJ, Ouagazzal A (1998) Bimodal modulation by nicotine of anxiety in the social interaction test: role of the dorsal hippocampus. Behav Neurosci 112:1423-1429.

Galeote L, Berrendero F, Bura SA, Zimmer A, Maldonado R (2009) Prodynorphin gene disruption increases the sensitivity to nicotine selfadministration in mice. Int J Neuropsychopharmacol 12:615-625.

Gilbert DG, Meliska CJ, Williams CL, Jensen RA (1992) Subjective correlates of cigarette- smoking-induced elevations of peripheral betaendorphin and cortisol. Psychopharmacol 106:275-281.

Hasebe K, Kawai K, Suzuki T, Kawamura K, Tanaka T, Narita M, Nagase H, Suzuki T (2004) Possible pharmacotherapy of the opioid kappa receptor agonist for drug dependence. Ann N Y Acad Sci 1025:404-413.

Heisler LK, Chu HM, Brennan TJ, Danao JA, Bajwa P, Parsons LH, Tecott LH (1998) Elevated anxiety and antidepressant-like responses in serotonin 5-HT1A receptor mutant mice. Proc Natl Acad Sci USA 95:15049-15054.

Hogg S (1996) A review of the validity and variability of the elevated plusmaze as an animal model of anxiety. Pharmacol Biochem Behav 54:21-30.

Horan P, Taylor J, Yamamura HI, Porreca F (1992) Extremely long-lasting antagonistic actions of nor-binaltorphimine (nor-BNI) in the mouse tailflick test. J Pharmacol Exp Ther 260:1237-1243.

Ismayilova N, Shoaib M (2010) Alteration of intravenous nicotine selfadministration by opioid receptor agonist and antagonists in rats. Psychopharmacol 210:211-220.

Isola R, Duchemin AM, Tejwani GA, Neff NH, Hadjiconstantinou M (2000) Glutamate receptors participate in the nicotine induced changes of metenkephalin in striatum. Brain Res 878:72-78.

Isola R, Zhang H, Tejwani GA, Neff NH, Hadjiconstantinou M (2009) Acute nicotine changes dynorphin and prodynorphin mRNA in the striatum. Psychopharmacology 201:507-516.

Jackson KJ, Carroll FI, Negus SS, Damaj MI (2010) Effect of the selective kappa-opioid receptor antagonist JDTic on nicotine antinociception, reward, and withdrawal in the mouse. Psychopharmacol 210:285-294.

Jenison RL, Rangel A, Oya H, Kawasaki H, Howard MA (2011) Value encoding in single neurons in human amygdala during decision making. J Neurosci 31:331-338.

Jones JL, Day JJ, Aragona BJ, Wheeler RA, Wightman RM, Carelli RM (2010) Basolateral amygdala modulates terminal dopamine release in the nucleus accumbens and conditioned responding. Biol Psychiatry 67:737-744.

Kalman D (2002) The subjective effects of nicotine: methodological issues, a 
review of experimental studies, and recommendations for future research. Nicotine Tob Res 4:25-70.

Knoll AT, Muschamp JW, Sillivan SE, Ferguson D, Dietz DM, Meloni EG, Carroll FI, Nestler EJ, Konradi C, Carlezon WA Jr (2011) Kappa opioid receptor signaling in the basolateral amygdala regulates conditioned fear and anxiety in rats. Biol Psychiatry 70:425-433.

Koob GF (2009) Brain stress systems in the amygdala and addiction. Brain Res 1293:61-75.

Kota D, Martin BR, Robinson SE, Damaj MI (2007) Nicotine dependence and reward differ between adolescent and adult male mice. J Pharmacol Exp Ther 322:399-407.

Land BB, Bruchas MR, Lemos JC, Xu M, Melief EJ, Chavkin C (2008) The dysphoric component of stress is encoded by activation of the dynorphin kappa-opioid system. J Neurosci 28:407-414.

Lê AD, Quan B, Juzystch W, Fletcher PJ, Joharchi N, Shaham Y (1998) Reinstatement of alcohol- seeking by priming injections of alcohol and exposure to stress in rats. Psychopharmacol 135:169-174.

LeDoux J (2003) The emotional brain, fear, and the amygdala. Cell Mol Neurobiol 23:727-738

Leri F, Flores J, Rodaros D, Stewart J (2002) Blockade of stress-induced but not cocaine-induced reinstatement by infusion of noradrenergic antagonists into the bed nucleus of the stria terminalis or the central nucleus of the amygdala. J Neurosci 22:5713-5718.

Liu X, Jernigan C (2011) Activation of the opioid $\mu 1$, but not $\delta$ or $\kappa$, receptors is required for nicotine reinforcement in a rat model of drug selfadministration. Prog Neuropsychopharmacol Biol Psychiatry 35:146-153.

Marco EM, Llorente R, Pérez-Alvarez L, Moreno E, Guaza C, Viveros MP (2005) The kappa- opioid receptor is involved in the stimulating effect of nicotine on adrenocortical activity but not in nicotine induced anxiety. Behav Brain Res 163:212-218.

Marlatt GA, Gordon JR (1985) Relapse prevention: maintenance strategies in the treatment of addictive behavior. New York: Guilford.

Marty MA, Erwin VG, Cornell K, Zgombick JM (1985) Effects of nicotine on beta-endorphin, alpha MSH, and ACTH secretion by isolated perfused mouse brains and pituitary glands, in vitro. Pharmacol Biochem Behav 22:317-325.

McKennell AC (1970) Smoking motivation factors. Br J Soc Clin Psychol 9:8-22.

McLaughlin JP, Marton-Popovici M, Chavkin C (2003) Kappa opioid antagonism and prodynorphin gene disruption block stress-induced behavioral responses. J Neurosci 23:5674-5683.

McLaughlin JP, Land BB, Li S, Pintar JE, Chavkin C (2006) Prior activation of kappa opioid receptors by U50,488 mimics repeated forced swim stress to potentiate cocaine place preference conditioning. Neuropsychopharmacol 31:787-794.

Melief EJ, Miyatake M, Bruchas MR, Chavkin C (2010) Ligand-directed c-Jun $\mathrm{N}$ - terminal kinase activation disrupts opioid receptor signaling. Proc Natl Acad Sci U S A 107:11608-11613.

Nealey KA, Smith AW, Davis SM, Smith DG, Walker BM (2011) $\kappa$-Opioid receptors are implicated in the increased potency of intra-accumbens nalmefene in ethanol-dependent rats. Neuropharmacol 61:35-42.
Peters MF, Zacco A, Gordon J, Maciag CM, Litwin LC, Thompson C, Schroeder P, Sygowski LA, Piser TM, Brugel TA (2011) Identification of short-acting $\kappa$-opioid receptor antagonists with anxiolytic-like activity. Eur J Pharmacol 103:27-34.

Pfeiffer A, Brantl V, Herz A, Emrich HM (1986) Psychotomimesis mediated by kappa opiate receptors. Science 233:774-776.

Picciotto MR (2003) Nicotine as a modulator of behavior: beyond the inverted U. Trends Pharmacol Sci 24:493-499.

Ramos A (2008) Animal models of anxiety: do I need multiple tests? Trends Pharmacol Sci 29:493-496.

Ribeiro SC, Kennedy SE, Smith YR, Stohler CS, Zubieta JK (2005) Interface of physical and emotional stress regulation through the endogenous opioid system and mu-opioid receptors 29:1264-1280.

Schindler AG, Li S, Chavkin C (2010) Behavioral stress may increase the rewarding valence of cocaine-associated cues through a dynorphin/ kappa-opioid receptor- mediated mechanism without affecting associative learning or memory retrieval mechanisms. Neuropsychopharmacol 35:1932-1942.

Shaham Y, Stewart J (1995) Stress reinstates heroin-seeking in drug-free animals: an effect mimicking heroin, not withdrawal. Psychopharmacology 119:334-341.

Shaham Y, Erb S, Stewart J (2000) Stress-induced relapse to heroin and cocaine seeking in rats: a review. Brain Res Brain Res Rev 33:13-33.

Shippenberg TS, LeFevour A, Heidbreder C (1996) $\kappa$-Opioid receptor agonists prevent sensitization conditioned rewarding effects of cocaine. J Pharmacol Exp Ther 1996 2:545-554

Shippenberg TS, Zapata A, Chefer VI (2007) Dynorphin and the pathophysiology of drug addiction. Pharmacol Ther 116:306-321.

Smith AP, Lee NM (1988) Pharmacology of dynorphin. Annu Rev Pharmacol Toxicol 28:123-140.

Stuber GD, Sparta DR, Stamatakis AM, van Leeuwen WA, Hardjoprajitno JE, Cho S, Tye KM, Kempadoo KA, Zhang F, Deisseroth K, Bonci A (2011) Excitatory transmission from the amygdala to nucleus accumbens facilitates reward seeking. Nature 475:377-380.

Tye KM, Stuber GD, de Ridder B, Bonci A, Janak PH (2008) Rapid strengthening of thalamo- amygdala synapses mediates cue-reward learning. Nature 453:1253-1257.

Tye KM, Prakash R, Kim SY, Fenno LE, Grosenick L, Zarabi H, Thompson KR, Gradinaru V, Ramakrishnan C, Deisseroth K (2011) Amygdala circuitry mediating reversible and bidirectional control of anxiety. Nature 471:358-362.

Walker BM, Zorrilla EP, Koob GF (2011) Systemic $\kappa$-opioid receptor antagonism by nor-binaltorphimine reduces dependence-induced excessive alcohol self-administration in rats. Addict Biol 16:116-119.

Wittmann W, Eduard SE, Rosskothen I, Gaburro S, Singewald N, Herzog H, Schwarzer C (2009) Prodynorphin-derived peptides are critical modulators of anxiety and regulate neurochemistry and corticosterone. Neuropsychopharmacol 34:775-785.

Zhu H, Lee M, Agatsuma S, Hiroi N (2007) Pleiotropic impact of constitutive fosB inactivation on nicotine-induced behavioral alterations and stress-related traits in mice. Hum Mol Genet 16:820-836. 